\title{
From the Mnemonic to the Literary: Exploring Memory in Select Works of Robin S. Ngangom and Kynpham Sing Nongkynrih
}

\author{
Sukla Singha \\ Department of English, Tripura University. Orcid: oooo-ooo3-4948-7297. \\ E-mail: shukla.singha85@gmail.com
}

\begin{abstract}
The Merriam Webster dictionary defines the word memory as the power or process of reproducing or recalling what has been learned and retained especially through associative mechanisms. Indeed Memory is a tricky thing; some we have, some have us. Writings (in English as well as those translated in English) coming from the North-East of India bear testimony to this association of personal memories to the kind of literature produced in this region of the country. Be it poetry or prose, be it the pen of Mamang Dai, Temsula Ao or Robin Ngangom, memories or recollections of the past have greatly shaped their present in different ways and its consequent reflection is seen in the kind of writing they engage themselves in.
\end{abstract}

Keywords: Memory, Manipur, Meghalaya, Home, Alienation.

\section{Introduction}

"In my memory are sky and earth and sea, ready at hand along with all the things that I have ever been able to perceive in them and have not forgotten. And in my memory too I meet myself - I recall myself, what I have done, when and where and in what state of mind I was when I did it. In my memory are all the things I remember to have experienced myself or to have been told by others. From the same store I can weave into the past endless new likenesses of things either experienced by me or believed on the strength of things experienced; and from these again I can picture actions and events and hopes for the future; and upon them all I can meditate as if they were present." (St. Augustine)

The Merriam-Webster dictionary defines the word 'memory' as the power or process of reproducing or recalling what has been learnt and retained especially through associative mechanisms. The human capacity to remember words and things, information and actions, and then to recall these for contemplation or for adjustment, is understood universally to be out memory. Parts of it may be hidden from us, to be recalled unselfconsciously, perhaps by sights or in settings or by an aroma, like Swann, in Proust's $A$ la recherche du temps perdu, who was transported back in time by a memory summoned by the taste of a biscuit dipped in a sweet decoction of flowers (Craig. B, 2002, p. 278). Memory not only retains facts, events and impressions, but also revives them all. According to the Stanford Encyclopedia of Philosophy:

Memory labels a diverse set of cognitive capacities by which we retain information and reconstruct past experiences, usually for present purposes. Memory is usually one of the most important ways by which our histories animate our current actions and experiences. Most (c) AesthetixMS 2016. This Open Access article is published under a Creative Commons Attribution Non-Commercial 4.0 International License (http://creativecommons.org/licenses/by-nc/4.o/), which permits non-commercial re-use, distribution, and reproduction in any medium, provided the original work is properly cited. For citation use the DOI. For commercial re-use, please contact aesthetixms@gmail.com. 
notably, the human ability to conjure up long gone but specific episodes of our lives is both familiar and puzzling, and is a key aspect of personal identity.

In Greek mythology, Mnemosyne was not only the goddess of memory; she was also the mother of the Muses, the goddesses of the various arts. Thus, there is a link between memory and literature (including history, whose Muse was Clio) and the other arts (Memory in Literature, n.d. para 1, p.1). In the Preface to Lyrical Ballads, William Wordsworth writes that poetry is the spontaneous overflow of powerful feelings which takes its origin from emotions recollected in tranquility. Although it might be a little cliché to quote Wordsworth in this context, but there is no denying the fact that his best-known works such as "Lines Written a Few Miles above Tintern Abbey", "The Solitary Reaper", "Ode: Intimations of Immortality" etc. have been preoccupied with the role of memory in individual life. For him, individual memory plays a vital role in the creative process and an experience does not end at that moment but it continues to linger in our minds as long as we are able to recall it.

The relationship between memory and literature is perhaps timeless, for it is often memories of the narrator or the poet that gets reflected in his/her writings. Memory, not only helps a writer recollect the things of the past, it also enables him to travel to the past and bring back many things with him that shape his present. Writings from the 'north-east' of India bear testimony to this association of personal memories to the kind of literature produced in this region of the country. In fact, most English writings (including those translated into English from different languages of the region such as Assamese, Khasi, Manipuri, Kokborok etc.) coming from the north-eastern region of India act as a cauldron of memory. Be it poetry or prose, be it the pen of Mamang Dai, Temsula Ao, Nabanita Kanungo or Robin S. Ngangom, memories or recollections of the past have greatly shaped their identities in the present and its consequent reflection is seen in the kind of writing they engage themselves in. In this sense, mnemonic reading may be considered as an alternative way of analyzing (English) writings from North-East India.

\section{Exploring Memory in Ngangom and Nongkynrih}

To begin with, the term 'north-east 'is certainly a blanket term that serves to act as a camouflage to bring the eight (Sikkim being the latest to join the league) states of Assam, Arunachal Pradesh, Meghalaya, Manipur, Mizoram, Nagaland, Tripura and Sikkim under one head. For example, when someone from Arunachal Pradesh or Manipur or Assam goes to a 'modern' city like Delhi, Mumbai or Bengaluru, he/she is instantly identified by the Delhites, Mumbaikars or Bangaloreans as a 'north-easterner' and not as an Arunachali or a Manipuri or an Assamese. To them, Assam, Tripura, Manipur, Brahmaputra, Gomati, Loktak etc. all are same and therefore, these mainlanders conveniently choose to call it as the 'north-east'. This simplistic and reductionist approach adopted by the mainland people towards the people belonging to this region creates a superimposed uniformity or homogeneity that tends to neglect the varied ethos of the different ethnic groups of the region. But it is 'impossible to homogenize' the people of this region since 'multiplicity' is what one finds here in terms of culture, ethnicity, language, food habits and even the literature produced in the region. As pointed out by Subir Bhowmik, India's 'north-east' is a post-colonial region created by the partition of the subcontinent. This is evident from the fact that one does not find the word 'north-east' in the ancient and medieval literatures of the country. It was only after the arrival of the colonizers that this word came into vogue. This implies that the naming of the region was done just for the sake of a convenient political surveillance by the colonizers. Sumanyu Satpathy considers this naming of the region as an unfortunate phrase that 'clearly comes from the centre-periphery model of location and carries on the colonial legacy...' 
(Satpathy. S, 2006) Veteran Poet K. Satchidanandan aptly says: "If Assamese Poetry and Manipuri Poetry are so different from each other, we can well imagine how diverse will other poetic traditions and practices of the rest of the north-eastern region with its host of beautiful minority languages be." Literature that comes from this region is generally classified under the head 'literature of the north-east', although the term is quite controversial and not many writers and poets of the region agree with such labelling of their works. But unfortunately, even after sixtynine years of independence, the region is still labelled as a "Mongoloid fringe" (Haskar. N, 1996). But that is not the only label given to this region. North-East India is still 'imagined' as a region with a flimsy historical and geographical link to the rest of India, a region inhabited by yellowfaced and small-eyed people who are absolutely no (?) different from one another, a region characterized only by the problems of insurgency, separatist and linguistic movements, tribal and non-tribal conflicts, superstitions, and most importantly, a region where people are still living in the dark ages amid mysterious dense jungles and rugged terrains, devoid of absolutely any intellectual enlightenment!

This paper is not an attempt to establish new definitions of the word 'memory' but instead, it wishes to argue that most (English) writings produced in the region may be studied as the 'Literature of Memory' with special reference to two poets of the region who have been writing in English since the late eighties. Transformation of the mnemonic space into a literary output comes almost naturally to these 'north-east' poets and writers who have dealt (and are still dealing) with the memory of two things in their writings: firstly, their rootedness in the traditions, folklores, myths, perennial beauty of the landscape of the region etc. and secondly, their encounter(s) with the different 'labels' mentioned in the preceding paragraph (although it is not impossible to discuss all writings here due to obvious constraints). For instance, Temsula Ao's collection of stories These Hills called Home: Stories from the War Zone has the Separatist Movement in Nagaland and the quest for Naga identity as the backdrop for the stories. She writes:

Memory is a tricky thing; it picks and chooses what to preserve and what to discard. Sometimes it is trivial that triggers the process of remembering a great loss. I remember how the memory of my mother's special curry of sun-dried fish used to haunt me long after her death, as though the absence of this exotic dish from the family menu made her death more real than anything else about her...But what do you do when it comes to someone else's memory and when the memory is of pain and pain alone? Do you brush it aside and say, it does not concern me...I have endeavored to re-visit the live [sic] of those people whose pain has so far gone unmentioned and unacknowledged.

Mamang Dai's poetry is marked by the unique and unfailing presence of memories of rivers and mountains, the way she grew up in Arunachal and her lament of the loss of old Adi traditions. The mountain, for her, is not merely another memory of childhood and youth but it forms part of a continuing relationship with the environment (Ghataraj, N. 2014, p. 420). When she explores the oral traditions of the Adi community of Arunachal Pradesh in her writings, "memory functions as an instrument of not only connecting the present with the past but the whole tradition of orality continues because of rememory by which folk narratives are retold from generations. Memory becomes a dynamic force for continuance of culture and is thus embodied in culture." (Ghataraj, N. 2014, p. 419). Similarly, Nabanita Kanungo, a Shillong born East-Bengali poet "appears to revisit stories from the past to arrive at a reconciliation and catharsis. The poet, who lives in Shillong, carries the burden of six decades of hurt" (V. Preetika, 2012, p.) that she seems to negotiate with in her writings:

It is not about what I want to take with me 
when I leave the city of my birth, rather what can be taken, or taken at all.

How much blue can be carried

behind the defeated sky of eyes

how many of their rain-speckled windows, how much sun can be poured into veins...

I am preparing for a day

when oranges will be a memoir.

This paper attempts to analyze select works of two eminent poets belonging to the North-East of India, Robin S. Ngangom from Manipur and Kynpham Sing Nongkynrih from Meghalaya and understand the role of memory/memories in shaping their literary output. Robin S. Ngangom and Kynpham Sing Nongkynrih are two of the most important names in the English poetry writing scene of North-East India. Robin is a bilingual poet and translator originally from Manipur but has been living in Meghalaya (Shillong) for more than thirty years now. Kynpham Sing Nongkynrih is a Meghalaya poet who writes in both Khasi and English. Both Robin and Nongkynrih teach English Literature at the North-East Hill University (NEHU), Meghalaya. These poets, along with another Meghalaya poet Desmond Leslie Kharmawphlang, had formed the popular 'The Shillong Poetry Circle' in $1988-89$ and started a journal called Lyric (that became defunct after some time mainly due to financial constraints). Robin and Nongkynrih together have edited two volumes of poems featuring the English poets of the region (including translated works of the region) namely Anthology of Contemporary poetry from the Northeast (NEHU Publications, 2003) and Dancing Earth: An Anthology of Poetry from North-East India (Penguin Books India, 2009). These anthologies have received accolades in the literary circle since they voice the varied ethos and voices of the region. Popularly known as 'The Shillong Poets', Robin and Nongkynrih "write about terrorism, insurgency, human right abuses, environmental and ecological concerns, erosion of tribal values, and the corrupt politician-businessman-bureaucrat nexus" (Das. P, 2008) which are deep rooted in their memories, memories which they grew up with and which they cannot do away with.

For the sake of convenience, I would like to take the liberty to group the (different) memories that operate in the poems of Robin and Nongkynrih under the following heads:

1. Memory of the (loss of) homeland (and the consequent yearning to go back to it).

2. Ecological memory.

3. Memory of rootlessness/homelessness/alienation.

4. Memory of love and relationships.

5. Memory of violence.

An interesting point to note here is that, these different (types of) memories in Robin and Nongkynrih cannot be studied in isolation, rather they are meant to be examined in close relation to one another because the recollection or resurfacing of any one of these memories shall automatically lead to the other. For instance Robin's memory of his deserted homeland brings to him not only the happy childhood days spent in his hometown, it also brings along the memories of bullets, killings, corruption and anarchy in the present state of Manipur as well as his not being able to identify (with the present Manipur) that probably makes him an alien in his own birthplace. This inevitably implies that Robin's memory of the lost homeland is associated with the beauty of, yearning for, and the present condition of the land that he cannot go back to. I 
would, therefore, not like to put these memories into strictly separate compartments, rather let these memories merge into one another as I attempt an analysis of select texts of these poets.

In the words of Nigamananda Das, Robin "is the most representative contemporary Indian English poet of the North-Eastern India." He has published three collections of poetry. The first collection of poems titled Words and the Silence (1988) was published by Writers Workshop, Kolkata, followed by Time's Crossroads (1994 Orient Longman), and the third book titled The Desire of Roots (2006) was published by Chandrabhaga Society, Cuttack. Besides, his works have been published in many national and international journals and online literary magazines and websites. Some of his poems have also been included in the Graduate and Post-Graduate English literature courses of few Indian universities. He was honoured with the Katha Award for translation in 1999. Robin writes on memories of the past as well as of memories of the past, the past that he left long ago in Manipur, his place of birth, which he longs to go back to, but he cannot, owing to political reasons. In a personal (informal) interview with the poet in Guwahati in October 2016, on being asked by the researcher if he wants to settle down in Manipur, the poet remarked, "Yes, I do wish to go back, I have friends and relatives there... I think my poems lie somewhere between Meghalaya and Manipur."

Robin, who was born in Singjamei district of Manipur (and has been living in Shillong for more than three decades now), could never really go back to his native land primarily because of political reasons. In his essay, Poetry in a Time of Terror, Robin writes:

"Manipur, my native place in Northeast India, is in a state of anarchy, and my poetry springs from the cruel contradictions of that land. Manipur boasts of its talents in theatre, cinema, dance and sports. But how could you trust your own people, when they entrust corruption, AIDS, terrorism and drugs to their children? Naturally, the Manipur that I ritually go back to from the laid-back hill town of Shillong every year is not the sacred world of my childhood..."

Memories of the 'lost' home seem to haunt him forever as he indulges into a sort of questionanswer game with himself, or may be with his birth place, Singjamei when he writes in the poem "Homeland I Left": "Homeland I left, one sultry day of adolescence/why do you keep distance?/I cannot recall your intimate voices of night/ nor connect living faces with names."(Ngangom 1988: 10) This memory automatically seem to trigger the memories of his boyhood days that he so wishes to get back had he the power to travel back in time. He continues to interrogate in the lines: “...Do you remember/naked unaware we made muddy /our lukewarm river, who gave us sores in return? /How we enacted/ our truant dramas, in houses/ of bushes on our hillock, smoking/ bidis and playing dirty little games! /How we loved the colourful festivals/ And catching fish from stagnant pools/.../How we hunted small-game in the rice fields/And covered every lane of Imphal on bicycles/Making passes at almost every girl!" (Ngangom 1988: 10)

But the peaceful and beautiful Manipur that he knew of has changed considerably now. He says,

"Perhaps we all mourn the fate of our homeland, as the Sicilian poet Quasimodo has said. And though I've never remotely imagined myself as any conscience-keeper, I've often tried to speak of my people, and of the terrible things happening in Manipur."

His deep anguish is expressed in the lines: "I hear a wicked war is now waged/on our soil, and gory bodies/dragged unceremoniously/through our rice fields. That they have/dropped the word 
"shame"/from the vocabulary/and the newly-rich are ruling our homes./I hear that freedom comes here, only/if escorted by armed men." (Ngangom 1988: 10-11)

Robin seems to share a love-hate relationship with his native land. He is absolutely fond of and often gets nostalgic about it, but when he becomes aware of the real situation of his hometown, he feels like escaping from it once again. His memory of the happy vibrant days are depicted in the poem "Singjamei": "Now nocturnal hours fall/returning us to childhood/and roams your milling bazar;/the stalls of seasoned smoked fish/rotting betelnut, bunches of magnolia/ and herbs, handpicked for maidens and/ moonlit nights: $\mathrm{O}$ how they all return!/.../we are juvenile wooden wheels/of chariot festivals..."(Ngangom 1988: 15). Robin's rootedness in his Meitei culture is evident in the way he cherishes the festivals of colours and the chariots (Yaoshang and Kaang festivals), two of the most important rituals in Manipuri community. In fact, he has confessed of his rootedness in his Meitei culture. But just when he is about to delve deep into the world of nostalgia of his homeland, Robin is pushed back to reality when he remembers the present Singjamei/Manipur, a land scarred with the images of child prostitutes and black-marketers, leading to his refusal to go back to her: "And the long and winding road/to a homecoming only greets/the beckoning smile of a child prostitute/or chattering dead young mothers/.../And I deserted you once more" (Ngangom 1988: 15-16). In the poem "Everywhere I Go", Robin says that he carries his homeland with him everywhere he goes, and he "looks for it in protest marches on the streets of the capital." He makes it clear that he is one of those wretched young men who do not wish to return to such a homeland, "but would rather in a city's sordid restaurants because devils and thieves rule their home" but he cannot deny the fact that wherever he goes, he cannot get his homeland out of his heart as he says "the tunes of my homeland...dance in my blood."

Kynpham Sing Nongkynrih was born at Cherrapunjee and educated in Shillong. His collections of poetry in English Moments (1992) and The Sieve (1992) were published by Writers Workshop, Kolkata. His poetry collection The Yearning of Seeds was published by HarperCollins Publishers in 2011. Besides, he has published a number of books in Khasi. He has been widely published in national and international journals and honoured with awards such as the first North-East Poetry Award (Tripura 2004). Award winning Welsh poet Nigel Jenkins writes of Nongkynrih:

"His is an enviable lyrical gift, informed by wide and sophisticated reading, yet rooted in the fertile soil of his native Khasi Hills..."

Just as Robin is continuously haunted by memories of Singjamei, for Nongkynrih, Cherrapunjee is his Innisfree. Cherrapunjee was where he was born and occupies most of his memory and perhaps acts as his muse. It would not be wrong to say that in Nongkynrih, memory becomes Cherrapunjee. In Moments, the poet seems to be obsessed with the beauty of his birthplace and he addresses her as 'Meikha' (used in the sense of a 'mother' in the poem) as he goes on remembering her beauty in the poem "Cherra": "Cherra, dear Meikha,/crowds have sung for you/competing Sunday bells/tolling abroad your pulchritude/those foamy-white cascading ornaments/your roaring falls/ those leafy green dresses/your musical forests;"(Nongkynrih 1992: 20).

Ecological memory (or eco-memory) of the beauteous aspects of hills and valleys, folktales and myths, mighty rivers, forests and flowers, mist and fog come alive with the stroke of the creative and imaginative brush of thoughts and words of these poets. Nongkynrih describes how serene Cherrapunjee (with all her waterfalls) looked in autumn, winter, summer and rains. In Moments, he writes a series of poems titled "A Day in Cherrapunjee" In the memories of 
Cherrapunjee, are rooted his 'rememories' of Khasi folklores that are an indispensable part of the Khasi cultural identity. In the poems included in Moments and The Yearning of Seeds, he explores the popular beliefs of his Khasi identity with which he grew up, such as the legend of "Lalyngngi" (an orchid from Khasi folklore), "Likai" (Non ka Likai Falls named a woman called Likai who had committed suicide there) and so on: "This is Likai/ queen of waterfalls/and proudest possession/of our land." (Nongkynrih 1992: 27) "But I can feel gentle autumn in the sun/And there's no dust in the wind./.../ This is a day in Cherra,/come to Cherra and get wet,/unbothered by the stains of mud" (Nongkynrih 1992: 22-23). He continues to praise her: "Cooler than the breath of autumn!/ Sweeter than a lover's acceptance!/Purer than the thoughts of an angel!/Dainthlen, what may one call your stream,/gathered like dewdrops/in glittering pools of crystal"(Nongkynrih 1992: 24). "There is peace in Cherra/Where a man may walk/The timehonoured paths unperturbed/And breathe invigorating air/Without affliction to his nose."(Nongkynrih 1992: 47-48)

According to Robin, "A writer can be influenced by anything, and he would be able to write in any country other than his own. But he has to reclaim his individual voice. It is natural for someone from the Northeast of India to exploit the folk traditions he grew up with, to write of the hills when he is living in the hills. It is Shillong that has moved me into this kind of poetry, Shillong with its gentle hills, the Khasis with their rich oral literature." Robin's memory of how Meghalaya became his 'home' away from home is expressed in the lines where he explores the Khasi legend of the "seven huts" and confesses how Meghalaya accepted a fugitive like him who was escaping from his own birthplace: "Seven Huts of my solitude, my first love/Your rain, your wind, searched my face for signs/Of guilt when I first disembarked; a fugitive/Fleeing from ties of blood and desire" (Ngangom 1988: 29).

But like Robin, Nongkynrih too realizes that the Cherra of his memories has changed way too much than he could have imagined. His lament accompanied by disgust is strewn in the lines: "Rumours are rampant of the land being raped/Of people raping it and clawing each other" (Nongkynrih 1992: 19). Nongkynrih's Cherrapunjee "used to be a metropolis of birds" but now the poet calls it a "ghost town" where "the music is gone" and where "Now only ruin remains/Beyond those blue hills/The other side of the chasm" (Nongkynrih 1992: 28). This memory of the beautiful land is further blurred by the lines in the poem "The Ancient Rocks of Cherra" thus: "There is nothing remarkable here/ only this incredible barrenness" (Misra 2011: 67). Robin speaks of a similar loss of memory in these lines in the poem "The First Rain": "I'll leave the cracked fields of my land/and its weeping pastures of daybreak /Let wolves tear our beloved hills./.../ I'll leave the bamboo flowering/in the groves of my childhood/Let rats gnaw at the supine map/of what was once my native land" (Misra 2011: 46).

Memories associated with the feeling of rootlessness or homelessness often make their presence felt in the works of both Robin and Nongkynrih. While Robin experiences alienation owing to his inability to go back to his own place of birth as well as the infiltration of 'outsiders' in both Manipur and Meghalaya causing a threat to old values of the land, Nongkynrih's sense of alienation comes primarily from his memories of how he gets treated outside his native land. In "Poem for Joseph", Robin speaks of how he does not have a sense of belonging to his place of birth, and Singjamei, in turn, seems to have abandoned him too. He says he has nothing (in Manipur) to return for, although the longing to go back and be a part of it is quite evident in the following lines:

"It is never too late to come home."

But I need a homeland 
where I can recognize myself,

just a map or even a tree or a stone,

to mark a spot I could return to

like a pissing animal

even when there's nothing to return for.

(Ngangom 2006: 74)

His concern for the loss of cultural values by the intruders is reflected in his third volume of poems aptly titled The Desire of Roots, where he speaks of the threat imposed by the outsiders who are desperate to replace the old values of the land: "they can never learn/our songs, or feel the drumbeats of our hearts" (Ngangom 2006: 19). His desire to go back to where he was born is resonated when he writes:

$$
\begin{aligned}
& \text { When you leave your native hills } \\
& \text { I can only speak of lost times, } \\
& \text { and of sorrow and blood. And I write } \\
& \text { these letters of winter, asking you } \\
& \text { to return to the hills... }
\end{aligned}
$$$$
\text { (Ngangom 2009: 200) }
$$

To Nongkynrih, to be perceived and treated as an 'alien' in one's own country indeed contribute to this whole notion of rootlessness (Imsong. I.T, 2011). He wants to do away with such memories but this is the reality that he faces every time when he is labelled as a 'non-Indian' owing to his 'looks' and the place he comes from. His series of poems based on and addressed to Delhi can be placed in sharp contrast to the Cherrapunjee poems. Delhi refuses to accept him as an 'Indian' and clearly, he does not cherish his memories of the capital city: "In Delhi, I felt lost/The language is not our bazaar Hindi/The driver asked / From where we had come/We told him of Shillong/But the man had never heard of it./He did not even take us for Indians/I felt alienated"(Nongkynrih 1992: 76). His concluding remarks clearly speaks of the non-acceptance of the margins (NorthEast) by the mainland (Delhi): "Where were the hills? / And the cool sensuous breeze? /This land, I thought/Has no use for the hills/And those in the hills" (Nongkynrih 1992: 71). Nongkynrih's memory of I. K .Gujral's visit to the capital city of Meghalaya is filled with sarcasm. The poet considers the minister nothing but a superfluous outsider pretending to be sympathetic with the natives and thus trying to get into their heads by making false promises. Gujral's visit, marked by "strident sounds of sirens" sent shockwaves among the natives who associated it with "warnings in war-time bombings" reminding them of the wars fought for the assertion of ethnic identity in Meghalaya, of the "deaths, injuries, and humiliation resulting from 'insurgencies' and 'counterinsurgency operations,' as well as the hidden hurt that citizens quietly endure”(Barua. S, 20o8): "He came like a threat/And scam tainted ministers/Were in a cold sweat/ But he left like a defused bomb./They wandered/ what he could have seen/ of the land/ what of the people/ he could have learnt/ when he came/ like the snapping of fingers/ They wondered/And sought answers/ Like little children./ Only the bamboos watched in silence/ Too used to the antics of men" (Nongkynrih 2011: 11).

Memory of love and relationships, be it with the ecology of the lost homeland or with the family left behind are explored by these poets in many of their poems. Nongkynrih's memory of his mother 'shocks' us in his use of the language, but is very relatable in the Khasi way of life, or for that matter the indigenous way of life which is very different from the perspective of describing an 'Indian' mother by a Delhi or Bangalore based poet. His "poetry is marked with a difference, characterized by regional ethos and tribal heritage, which essentially deters critics from situating him in the similar bandwagon as the charismatic mainland Indian-English 
poets."(Bhattacharjee. S and S. Guha, 2014). In “Blasphemous Lines for Mothers”, he remembers his mother:

My mother is retired, toothless, diabetic and bedevilled

By headaches and a blinding cataract. In short, she is,

She is a cantankerous old woman.

I remember the time when she was a cantankerous

Young woman. When she took an afternoon nap,

she was tigerish: 'You sons of a vagina!'

...If I get you I'll lame you! I'll maim you!... ～(Ngangom 2009: 207)

His then recalls how he was forced to wash his mother's "blood-stained rags" and how she "would do her job in a trash can" since they had no sanitation facilities available back then in his village. He says "Refusal was out of question" and that he could never say no to her since she was the head of the family (referring to the matrilineal culture among the Khasis). The poem ends in with his gratitude to her:

There's only one

thing commendable I will admit about her:

if she had married again and not been

the cantankerous woman that she is,

I probably would not be standing

here reading this poem today.

(Ngangom 2009: 209)

In another poem titled 'Lines Written to Mothers Who Disagree with their Sons' Choices of Women", Nongkynrih writes in a cheeky playful tone that mothers are often disapproving of their sons' choice of life partners. He writes that "a garland of threats" has been placed around his neck (perhaps by his mother who does not like the girl he loves) and consequently he requests her "Leave cherries to winter, mother/ love to seasoned lovers" (Nongkynrih 2011: 89). In most of his Cherrapunjee poems, Nongkynrih keeps alluding to a certain Ruby (his wife). Throughout his memories of Sohra (another name for Cherrpunji), she accompanies him, rather he makes her accompany him. He says, "Ruby, ours is a culture of love and the free will /We are not of plains who submit like an ass and marry like a business deal..." The poetry collection titled The Sieve is dedicated to her and the poet time and again expresses how he feels her presence everywhere even after she's gone, how he yearns to be with her even when she's not there.

We met, unknown, in the train,

Brought together by a common tour.

We met, we looked and we loved,

Fondled and kissed.

But then, the train ground to a halt

And unknown, she was gone;

vanishing without rain,

but for memories

lingering like a lost soul.

(Nongkynrih 1992: 14)

because you inspire me, my love, 
because your heart has been my lover, though strangers yet we are.

And out of that loving union, my love, I have fathered forth some poems, My little darling daughters.

And you their darling mothers

Who will say that you and I

Are not already man and wife?

(Nongkynrih 1992: 27)

In the poem "A Farewell Letter to Cherries" dedicated to a certain Professor MB, Nongkynrih speaks of 'memory': "Dear brother, we live in our memory/in the memory of the world:/ stoking that memory with fondness/is all that we can do./ We can do no more/we can do no less" (Nongkynrih 2011: 69).

Robin's memory of his mother and the representation of it in his "A Poem for Mother" is poignant and moving. The poem appears as a tribute to his biological mother as well as to the motherland that he 'deserted'. He calls his mother "Palem Apokpi" one who gave birth to him. He apologizes for leaving her ten years ago but says he is still his "shy son with a voracious appetite" and also the same old son "who gave you difficult times during his school days, running after every girl he met..." His mother is like a typical mother who takes all pains to make her family happy:

I know how you toil as all mothers do

For unmarried sons and ageing husband And liberated daughters-in-law.

Your lips couldn't blossom into a smile, Lines have furrowed your dear face and The first signs of snow are on your hair. Today, as on every day you must have risen With temple bells before cockcrow, swept The floors and after the ritual bath, cooked For the remainder of us...

(Ngangom 1988: 25)

The memory of the ageing mother with who took care of him during his boyhood days, her teachings that "Money and time do not grow on trees", her wrinkled skin and shallow smiles, her toiling forever etc. all may be seen as Manipur's present situation of political and economic crisis where curfews, killings, corruption have become household names blurring the beauty and peace of the old Manipur that he left. He regrets that he could not give back anything to his mother (land):

Only I deserted much and left

So little of myself for others

To remember me at home.

I'm sorry Palem

I've not inherited anything...

Forgive me, for all your dreams

of peace and rest during your remnant days 
I only turned out to be a small man, with small dreams and living a small life. (Ngangom 1988: 24-25)

In another poem, Robin remembers the Meitei writer Pacha whose untimely passing away left a void in the poet's heart and mind. He writes:

To your uneventful death, Pacha

the stones hurled at your demented name, and the doors closed on your life it is fitting that none mourn the face of your memory they slapped;

from booze artist Pacha, to lunatic Pacha. (Ngangom 2006: n.p)

Memory of violence has a profound presence in Robin, so much so, that he has often been 'accused' of being an exclusively 'political poet', although he does not subscribe to these views. He is not bothered by any such labelling since he writes on nature and relationships with ease as much as he writes on violence prevailing in his homeland. Manipur is caught between the Armed Forces Special Powers Act (AFSPA) which gives license to the armed militant forces to kill any civilian on the basis of mere suspicion, and the underground banned groups (who call themselves 'revolutionaries') who keep on demanding money from local people or else kill them if their demands are not fulfilled. Speaking of why his poems are "riddled with bullets", Robin says:

"The writer from Northeast India, consequently, differs from his counterpart in the mainland in a significant way. While it may not make him a better writer, living with the menace of the gun does not permit him to indulge in verbal wizardry or woolly aesthetics, but is a constant reminder that he must perforce master the art of witness. ...

In contemporary Manipuri poetry, there is a predominance of images of bullets, blood, mother, the colour red and, paradoxically, flowers too. A poet from Imphal told me of how they've been honing the poetry of survival with guns pressed to both temples: the gun of revolution and the gun of the state."(Ngangom. R.S, 2013).

Manipur was allegedly made a part a part of the Indian Union in 1949 and till date the cry for a 'real' homeland could be heard in Manipur that manifests itself in its gory forms:

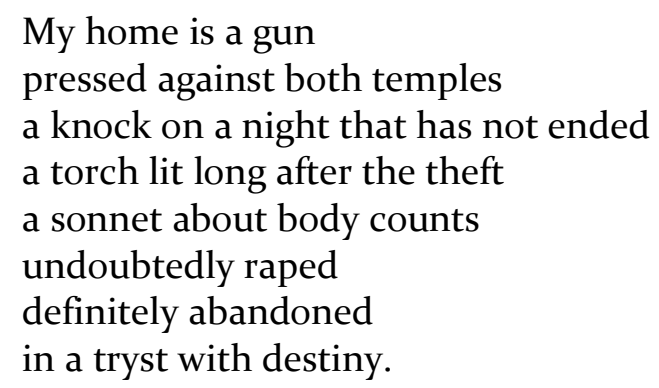

(Ngangom 2005: n.p)

It is therefore natural for a poet such as Ngangom to write on the kind of violence that is embedded in his memory, which he cannot separate from his native land. Jaideep Saikia points out in Frontier in Flames, "Most states have been besieged by three to five decades of armed conflict; ranging from demands for self-determination and greater autonomy to assertion of complete secession from India." Unfortunately, for the (common) people of Manipur, the strife may be seen as three-fold: the clash between the AFSPA holders and the natives, the inter-ethnic conflicts among the Kukis, the Naga and the Meiteis, and not to forget those natives demanding separate statehood sacrificing the lives of innocent young men in the name of a 'revolution' who 
perhaps have no idea what they are being dragged into. In the poem titled "Revolutionaries", Robin says that he grew up with "revolutionaries" who had "asked poets in their lower ranks to compose patriotic songs for a county which cannot be found on any map." He further exposes how his childhood friend who "smelled of straw and cattle" (implying that he used to work in field or a cattle farm to make a living) was perhaps lured into the political game by the honchos who showed him a big dream only to turn him into a "sharpshooter of a revolutionary band" who "buried a pistol... just before he went underground." In the poem "Native Land", Robin writes on the hard times that Manipur is going through, in the name of 'nationalism' and exposes the reckless violent killings:

First came the scream of the dying

in a bad dream, then the radio report, a newspaper: six shot dead, twenty-five houses razed, sixteen beheaded with hands tied behind their backs inside a church ... As the days crumbled, and the victors and their victims grew in number, I hardened inside my thickening hide, until I lost my tenuous humanity.

I ceased thinking of abandoned children inside blazing huts still waiting for their parents.

In "The Strange Affair of Robin S Ngangom", the poet describes yet another memory of violence that he was made to witness, in the lines: "When I turn with a heavy heart/ towards my burning land/ the hills, woman, scream your name/... instead of your musl/ I inhale the acrid smoke/ of gelignite and pyres" (Ngangom 2006: 67). He exposes the hypocrisy of the so called law-keepers of the nation (referring to AFSPA) who rape women of Manipur at their will. He says, "I want to tell my poet friends/ of the twelve mothers who themselves/ and asked soldiers to rape them..."(Ngangom 2011: 47). Curfews/Bandhs have become an everyday thing in Manipur now resulting in the stagnant condition of the state's economy. In the poem "Curfew" he writes, "The once groaning streets are muted/... /People were killed in a lawless firing /and the streets today/observe long hour silence for the departed" (Ngangom 1988: 66). He remembers stories of violence told by his grandmother, of how Manipur became involved in the Second World War and how it was "...not our war" (Ngangom 1988: 12). He seems to lament the forceful merging of Manipur to the Indian Union and says, "at cockcrow one morning we found/ ourselves belonging to a nation/ What happens when our bodies leave us behind/ and even our songs must lie/ damp in a corner?" (Ngangom 1988: 12-13).

Meghalaya is also a victim to political unrest and violence practiced by militia groups. The conflict is not only between the Khasis and the outsiders from the 'mainland', but it is also an internal conflict where young Khasis are being lured to join militant groups in the name of nationalism. He recalls a strike/bandh and says:

When for the umpteenth time

the region's liberators

clamped a bandh on Republic Day

there was nothing else to do

but watch the grey winter sky 


$$
\text { breeding ill will. }
$$

(Nongkynrih 2011: 15)

In another poem "Sundori", Nongkynrih writes: "Beloved Sundori/ Yesterday one of my people/ Killed one of your people/ And one of your people/ Killed one of my people/ Today they have both sworn/ To kill on sight." (Nongkynrih 2011: 12)

\section{Conclusion}

In this paper, I have attempted to present a slice of the memory/memories that we find in Robin and Nongkynrih. It would not be wrong to say that both these poets indulge in deep nostalgia that reflects in their writings and in the course of such an indulgence, their individual memories often pave way for a collective memory of the Meitei or the Khasi communities of Manipur and Meghalaya respectively. However, it would be an understatement to say that memory is just a tool to reconstruct the past. This is because, in Robin and Nongkynrih, what they write is memory and in the process, they 'see' and 'become' memory too:

"To see" means not only to have before one's eyes. It may mean also to preserve in memory. "To see and describe" may also mean to reconstruct in imagination. A distance achieved, thanks to the mystery of time, must not change events, landscapes, human figures into a tangle of shadows growing paler and paler..." (Milosz)

\section{References}

Augustine. S., \& Sheed, F.J.1. (1943) The Confessions of St. Augustine. London: Sheed \& Ward.

Ao, T. (2006). These Hills Called Home: Stories from a War Zone. New Delhi: Penguin Random House India Pvt. Ltd.

Barua. S. (2008) Durable Disorder: Understanding the Politics of Northeast India. New Delhi: Oxford University Press.

Bhattacharjee, S \& Guha, S. (2014) Towards a Poetics of Reconstruction: Reading and Enacting Identity in Kynpham Sing Nongkynrih's Poetry. Rupkatha Journal on Interdisciplinary Studies in Humanities. ( VolVI, No.2, 2014. pp. 83-94) Retrieved on October, 2014. http://rupkatha.com/V6/n2/10 Nongkynrih poetry.pdf

Bhowmik, S. (1998) "North-East India: The Evolution of Post-Colonial Region.” Wages of Freedom, Partha Chatterjee (ed.), New Delhi: Oxford University Press.

Craig, B.L. (2002) "Selected Themes in the Literature on Memory and Their Pertinence to Archives." The American Archivist (Vol. 65, pp. 276-289.) Retrieved on 25 October, 2016. http://americanarchivist.org/doi/abs/10.17723/aarc.65.2.362773030n128265

“Czeslaw Milosz - Noble Lecture” (1980). Retrieved on 15 October, 2016. http://nobelprize.org/nobel prizes/literature/laureates/1980/milosz-lecture-en.html/

Das, N. (2013). Contemporary English Poetry of Manipur. Muse India Archives. Issue 47. Retrieved on 12 January, 2015. http://www.museindia.com/featurecontent.asp?issid=47\&id=3897

Das, P. (2008) "Anthology -making, the nation and the Shillong poets." Economic $\mathcal{E}$

Political Weekly. 2008. www.epw.in/journal/2008/42/.../anthology-making-nation-and-shillong-poets.html 
---. (n.d). Waiting to be Taken Onboard: The Poetry of Robin Ngangom, Desmond Kharmawplang, and Kynpham Sing Nongkynrih (pp. 1-15), Retrieved on 20 Januray 2015. http://www.academia.edu/2467910/WAITING_TO_BE_TAKEN_ONBOARD_THE_POETRY_OF_ROBI N_NGANGOM_DESMOND_KHARMAWPLANG_AND_KYNPHAM_SING_NONGKYNRIH

Gahatraj, N.(2014) "Cultural Memory and Remembrance: Exploring Orality and Identity in Northeast Poetry." Research Scholar. (Vol. 2, Issue II, May 2014. pp. 416-423)

Haskar, N. (1996) "Movement of Self Assertion in the Northeast", Madhushree Dutta, Flavia Agnes and Neera Adarkar, eds., The Nation, the State and Indian Identity. Kolkata: Stree.

Imsong, I. T. (2011) "Tension of Root and Rootlessness in Northeast Poetry". Journal of Literature, Culture and Media Studies, (Vol.-III, No. 5 \& 6, December 2011, pp. 244-255) Retrived on 15 October 2014. www.inflibnet.ac.in/ojs/index.php/JLCMS/article/view/1094

K. Satchidanandan. (2013) "Vibrant Contemporary Writing from the North-Eastern Region: Overcoming Marginalization of Culture and Literature." Retrieved on 12 January 2015. http://www.frontline.in/columns/K Satchidanandan/voices-from-the-hills/article4742386.ece

Kanungo, N. (n.d) ("What shall I take with me when I leave Shillong." Web. 12 Ocober, 2016. http://prairieschooner.unl.edu/fusion/feast/what-ill-take-me-when-i-leave-shillong

Ngangom, R.S., and Nongkynrih K.S. (2009) Dancing Earth: An Anthology of Poetry from North-East India. New Delhi: Penguin Books.

Ngangom, R.S. (1988) Words and the Silence. Calcutta: Writers Workshop.

---. (2006) The Desire of Roots. Orissa: Chandrabhaga.

---. (2011) "The First Rain”. The Oxford Anthology of Writings from North-East India:Poetry and Essays. Ed. Tilottoma Misra. New Delhi: Oxford University Press.

---. (2011) "Everywhere I Go". The Oxford Anthology of Writings from North-East India: Poetry and Essays. Ed. Tilottoma Misra. New Delhi: Oxford University Press.

---. (2006) "Poetry in a Time of Terror." Sarai Reader 2006: Turbulence. Web. 10 January, 2013. www.sarai.net/publications/readers/06/turbulence/03 robin.pdf

Nongkynrih, K.S., and Ngangom R.S. (2003) eds. Anthology of Contemporary Poetry from the North-East. Shillong: North Eastern Hill University.

Nongkynrih, K.S. (1992) Moments. Calcutta: Writers Workshop.

---. (1992)The Sieve. Calcutta: Writers Workshop.

---. (2011) "The Ancient Rocks of Cherra". The Oxford Anthology of Writings from North-East India: Poetry and Essays. Ed. Tilottoma Misra. New Delhi: Oxford University Press.

---. (2011) "A Farewell Letter to Cherries".The Oxford Anthology of Writings from North-East India: Poetry and Essays. Ed. Tilottoma Misra.New Delhi: Oxford University Press.

"Memory" (n.d) Merriam Webster Dictionary. Retrieved on 15 October, 2016. http://www.merriamwebster.com/dictionary/memory

Saikia, Jaideep (2007) (Ed.) Frontier in Flames: North-East India in Turmoil. New Delhi: Penguin India.

Satpathy, Sumanyu.(2006) "Locating Cultures: A Semi- Academic essay on the English Poetry of the NorthEast.” Muse India Archives. (Issue 8). Retrieved on 10 October, 2013. www.museindia.com/viewarticle.asp? $\mathrm{myr}=2006 \& \mathrm{issid}=8 \& \mathrm{id}=348$

Sutton, John. (2016) "Memory". The Stanford Enclycopedia of Philosophy (Summer 2016 Edition), Edward N. $\begin{array}{llllll}\text { Zalta } & \text { (ed.). } & \text { Retrieved } & & \end{array}$ http://plato.standford.edu/archives/sum2016/entries/memory/ 
Venkatakrishnan, P.(2012) "Mental Maps of Sorrow's Hills: Nabanita Kanungo and the Poetry of Witness." Indu Swami, ed. Exploring North-East Indian Writings in English-Volume II. Delhi, Sarup Book Publishers (Pvt.) Ltd, 2012.

Wordsworth, W. (1967) Lyrical Ballads. London: Oxford University Press.

Yumnam, N.(2014) “Home: Illusion and Disillusion in Robin S Ngangom’s Words

and the Silence". The Criterion. (Vol-5, Issue-VI, pp. 385-393) Retrieved on 20 October, 2016. http://www.the-criterion.com/V5/n6/Yumnam.pdf

Sukla Singha is a Research Scholar in the Department of English, Tripura University. Orcid: oooo-0oo3-4948-7297.E-mail: shukla.singha85@gmail.com 